\title{
The Judiciary and the Law of Maritime Delimitation
}

\author{
Setting the Stage \\ ALEX G. OUDE ELFERINK, TORE HENRIKSEN, \\ AND SIGNE VEIERUD BUSCH
}

\subsection{Introduction}

The development of the regimes of the continental shelf and the exclusive economic zone in the second half of the twentieth century has extended coastal state jurisdiction to almost half of the oceans. One study from 2011 indicates that the oceans cover 335 million square kilometres and that 130 million square miles are exclusive economic zone and continental shelf within 200 nautical miles from the baselines of coastal states. In addition, the continental shelf beyond 200 nautical miles from the baselines covers some 28 million square kilometres of ocean space. ${ }^{1}$ This extension of coastal state jurisdiction also dramatically increased the area of overlapping maritime zones of coastal states. Previously, coastal states in principle only had to delimit the territorial sea, which for most states measured only three nautical miles until the 1970s. With the advent of the continental shelf, this situation changed dramatically. ${ }^{2}$ For instance, in the

${ }^{1}$ See T. Schoolmeester and E. Baker (eds.), Continental Shelf; The Last Maritime Zone; Status in Sept. 2010 (UNEP/GRID-Arendal 2011) 16. It may be noted that the latter figure only concerns the continental shelf beyond 200 nautical miles in respect of which coastal states have submitted (preliminary) information in accordance with Art. 76 of the United Nations Convention on the Law of the Sea (LOSC). A number of states with significant continental shelf areas beyond 200 nautical miles, including Canada, Denmark, and the US, had not submitted such information in 2011, indicating that the actual area of continental shelf beyond 200 nautical miles is more than 28 million square kilometres.

2 As has been remarked by Gilbert Guillaume, the former President of the International Court of Justice (ICJ), '[d]elimitation of [maritime zones] was long considered a secondary question, involving the fixing of the boundaries between narrow territorial seas. Extension of state jurisdiction to the high seas and technological developments have made this into one 
North Sea, the entire seabed became part of the continental shelf of the coastal states, among others requiring boundaries between the UK and its neighbours on the European continent. To give one other example, while Norway and the former Soviet Union only shared a territorial sea boundary in the Varanger Fjord, their continental shelf covered the entire Barents Sea and a part of the central Arctic Ocean to the north of Svalbard. While the territorial sea boundary measures 22.7 nautical miles, the continental shelf boundary that was agreed upon in 2010 between Norway and the Russian Federation has a length of more than 920 nautical miles. $^{3}$

Rules on the delimitation of the continental shelf were first included in the 1958 Convention on the Continental Shelf, and the United Nations Convention on the Law of the Sea (LOSC), which was adopted in 1982, contains a delimitation provision for both the continental shelf and the exclusive economic zone. ${ }^{4}$ However, the rules contained in these conventions are of a general nature and provide limited guidance to states when they differ about the interpretation and application of the law and the appropriate method(s) to delimit their maritime boundaries. The clarification of the rules on maritime delimitation has been mostly achieved through the case law of the International Court of Justice (ICJ), arbitral tribunals and, more recently, the International Tribunal for the Law of the

of the main territorial issues of the last 30 years' (G. Guillaume, Speech by His Excellency Judge Gilbert Guillaume, President of the International Court of Justice, to the Sixth Committee of the General Assembly of the United Nations; 31 October 2001, available at www.icj-cij .org/court/index.php?pr $=81 \& \mathrm{pt}=3 \& \mathrm{pp} 1=1 \& \mathrm{p} 2=3 \& \mathrm{pp} 3=1$ ).

3 Treaty between the Kingdom of Norway and the Russian Federation concerning Maritime Delimitation and Cooperation in the Barents Sea and the Arctic Ocean of 15 September 2010 (English translation available at www.un.org/Depts/los/ LEGISLATIONANDTREATIES/PDFFILES/TREATIES/NOR-RUS2010.PDF). Most of the continental shelf delimited by this treaty already was part of the continental shelf under the definition contained in Art. 1 of the 1958 Convention on the Continental Shelf (Convention on the Continental Shelf, signed 29 April 1958, entered into force 10 June 1964, 499 UNTS 311). The figures on the length of these boundaries are mentioned in Om samtykke til ratifikasjon av overenskomst av 11. juli 2007 mellom Norge og Russland om den maritime avgrensning $i$ Varangerfjordområdet (St.prp. nr. 3 (2007-2008), 2 and Samtykke til ratifikasjon av overenskomst av 15. september 2010 mellom Norge og Russland om maritim avgrensning og samarbeid I Barentshavet og Polhavet (Prop. 43 S (2010-2011) 6-7.

${ }^{4}$ The delimitation of the territorial sea is addressed in Art. 12 of the 1958 Convention on the Territorial Sea and Contiguous Zone (Convention on the Territorial Sea and the Contiguous Zone, signed 29 April 1958, entered into force 10 September 1964, 516 UNTS 206) and Art. 15 of the LOSC. See further below for the explanation as to why this volume largely focusses on the delimitation of the continental shelf and the exclusive economic zone. 
Sea (ITLOS). As a result, the law of maritime delimitation has also been referred to as judge-made law. ${ }^{5}$

The delimitation of the maritime boundaries is one of the areas of the law of the sea that has been most heavily litigated. At the time of writing, twenty-nine cases on the delimitation of maritime boundaries have either been decided by the judiciary or are pending before a court or tribunal. ${ }^{6}$ The majority of this case law is concerned with the delimitation of the continental shelf and exclusive economic zone. Only three of these cases are exclusively concerned with the delimitation of the territorial sea; ${ }^{7}$ thirteen with the delimitation of the continental shelf or the continental shelf and the exclusive economic zone; ${ }^{8}$ and thirteen with the delimitation of the territorial sea, continental shelf, and exclusive economic zone. ${ }^{9}$ In addition, it may be noted that in comparison to the delimitation of the territorial sea, the delimitation of the continental shelf and the exclusive economic zone has led to much more controversy and debate. This may be illustrated by the fact that monographs on the law of maritime delimitation in general focus on the continental shelf and the exclusive economic zone and pay limited attention to the delimitation of the territorial sea. ${ }^{10}$ The fate of the delimitation provisions contained in the 1958 Conventions on the Territorial Sea and the Contiguous Zone and the Continental Shelf, respectively, also attests to the larger measure of controversy surrounding the delimitation of the continental shelf and the exclusive economic zone. Article 12 of the former Convention was included almost verbatim as

${ }^{5}$ For instance, President Guillaume of the ICJ in a speech to the Six Committee of the General Assembly of the United Nations submitted that the law in this field had been completely reunified by the Court's judgment in Maritime Delimitation in the Area between Greenland and Jan Mayen (Denmark v. Norway) ([1993] ICJ Rep. 38) and that this law 'has reached a new level of unity and certainty' through the development of the case law (Guillaume, n. 2); see also below, Sections 1.2 and 1.5 of this chapter for further references to this speech.

${ }^{6}$ For an overview of these cases, see Table 1.1.

7 See ibid., entries A.1, A.5 and A.14.

${ }^{8}$ See ibid., entries A.2, A.3, A.4, A.6, A.7, A.8, A.11, B.1, B.2, B.5, B.6, B.7, and B.12. A number of these cases do not concern the delimitation of the exclusive economic zone but concern a 200-nautical-mile fishery zone instead.

9 See ibid., entries A.9, A.12, A.13, B.3, B.4, B.8, B.9, B.10, B.11, B.13, B.14, and B.15.

${ }^{10}$ See e.g. N. M. Antunes, Towards the Conceptualisation of Maritime Delimitation (Martinus Nijhoff Leiden 2003); E. D. Brown, Sea-bed Energy and Minerals: The International Legal Regime (Martinus Nijhoff Leiden 1992); T. Cottier, Equitable Principles of Maritime Boundary Delimitation: The Quest for Distributive Justice in International Law (Cambridge University Press Cambridge 2015); S. Fietta and R. Cleverly, A Practitioner's Guide to Maritime Boundary Delimitation (Oxford University Press Oxford 2015); Y. Tanaka, Predictability and Flexibility in the Law of Maritime Delimitation (Hart Oxford 2006); P. Weil, The Law of Maritime Delimitation: Reflections (Grotius Cambridge 1989). 
Article 15 in the LOSC. The almost identical provision contained in Article 6 of the Convention on the Continental Shelf was found to be unacceptable for a significant number of states at the Third United Nations Conference on the Law of the Sea (UNCLOS III). Articles 74 and 83 of the LOSC on, respectively, the delimitation of the exclusive economic zone and the continental shelf do not have any resemblance to Article 6. One explanation for this difference is that incidental geographical features in general will have limited impact on the equidistance line in the restricted area of the territorial sea. This impact may be much larger where the delimitation of the continental shelf and the exclusive economic zone is concerned. As a matter of fact, the ICJ pointed this out in its judgment in North Sea Continental Shelf. ${ }^{11}$ While the judgment provided states with strong arguments to reject the rule contained in Article 6 of the Convention on the Continental Shelf, ${ }^{12}$ the same does not hold true for the rule contained in Article 12 of the Convention on the Territorial Sea and the Contiguous Zone.

For the above reasons, the current volume focuses on the case law on the delimitation of the continental shelf and the exclusive economic zone and does not pay the same amount of attention to the delimitation of the territorial sea. At the same time, it is recognized that an analysis of the case law on the delimitation of the territorial sea may enhance our understanding of the delimitation of the continental shelf and the exclusive economic zone. For that reason, Chapter 2 of this volume is concerned with the delimitation of the territorial sea. This chapter in particular seeks to determine in which respects the regime of the territorial sea and its delimitation differ from that of the zones beyond the territorial sea.

The remainder of the current chapter provides some additional background information to the chapters that follow. Section 1.2 of the current chapter further introduces the research focus of the project that resulted in this volume. Section 1.3 then briefly comments on the development of the law on the entitlement to and delimitation of the continental shelf and the exclusive economic zone. As is explained in that section, the relevant rules contained in multilateral conventions and customary international law provide the framework against which developments in the case law have to be assessed. Section 1.4 of this chapter discusses the availability of third-party dispute settlement mechanisms to resolve disputes on the delimitation of the continental shelf and the exclusive economic zone.

${ }^{11}$ North Sea Continental Shelf Cases (Federal Republic of Germany/Denmark; Federal Republic of Germany/The Netherlands) (Judgment) [1969] ICJ Rep. 18, [8].

12 See further below at n. 23 . 
As this discussion illustrates, the option of third-party dispute settlement was considered to be relevant to maritime delimitation from the outset of the debate on substantive delimitation provisions. Section 1.4 also briefly discusses some general trends as regard the delimitation of the continental shelf and the exclusive economic zone through bilateral agreements and third-party dispute settlement procedures. Section 1.5 considers two issues that are not included in the subsequent chapters but still were considered to merit attention. These concern the question how the composition of judicial bodies may shape the law and whether criticism from beyond the bench may have had an impact on the development of the case law. The individual chapters of the volume are introduced in Section 1.6, while a final section presents concluding remarks.

\subsection{The Research Focus of the Book}

This volume is concerned with the case law of the ICJ, the ITLOS, and arbitral tribunals on the delimitation of the continental shelf and the exclusive economic zone. The title and specific research focus of the current volume and the research project at its basis have been inspired by the ICJ's judgment in Libya/Malta, where the Court observed that the justice which the courts had been applying in maritime delimitation cases is

justice according to the rule of law; which is to say that its application should display consistency and a degree of predictability; even though it looks with particularity to the peculiar circumstances of an instant case, it also looks beyond it to principles of more general application. ${ }^{13}$

It has been submitted that the law as developed by the judiciary has gradually become much more predictable - a development which started in the middle of the 1980s. This view has been regularly expounded in the academic literature. ${ }^{14}$ It has also been forcefully argued by influential judges.

13 Continental Shelf (Libyan Arab Jamahiriya/Malta), (Judgment) [1985] ICJ Rep. 39, [45].

14 See e.g. R. R. Churchill, 'The Bangladesh/Myanmar Case: Continuity and Novelty in the Law of Maritime Boundary Delimitation,' (2012) 1 Cambridge Journal of International and Comparative Law 137, 138, and 151; V. Degan, 'Consolidation of Legal Principles on Maritime Delimitation: Implications for the Dispute between Slovenia and Croatia in the North Adriatic,' (2007) 6 Chinese Journal of International Law 601, 609, 616-617, and 619; J. Shi, 'Maritime Delimitation in the Jurisprudence of the International Court of Justice,' 9 (2010) Chinese Journal of International Law 271, 290-291; Y. Tanaka, 'Reflections on Maritime Delimitation in the Cameroon/Nigeria Case,' (2004) 53 International and Comparative Law Quarterly 369, 405; Y. Tanaka, 'Reflections on Maritime Delimitation in the Romania/Ukraine Case before the ICJ,' (2009) 56 Netherlands International Law Review 397, 426; Weil, n. 10, 288. 
Of particular note is the speech of Gilbert Guillaume as President of the ICJ to the Sixth Committee of the General Assembly of the United Nations. ${ }^{15}$ Referring to the judgments in Tunisia/Libya and Gulf of Maine, Guillaume observes that

[a]t this stage, case law and treaty law had become so unpredictable that there was extensive debate within the doctrine on whether there still existed a law of delimitations or whether, in the name of equity, we were not ending up with arbitrary solutions. Sensitive to these criticisms, in subsequent years the Court proceeded to develop its case law in the direction of greater certainty. ${ }^{16}$

Guillaume observes that the Court began this development in Libya/Malta and Jan Mayen, in which cases the equidistance line was taken as a provisional starting point between opposite coasts. The process was completed in Qatar/Bahrain, when the Court found that equidistance also provided the starting point for delimitations involving adjacent coasts. ${ }^{17}$ Guillaume concludes that, as a result, 'the Court's case law, has reached a new level of unity and certainty, whilst conserving the necessary flexibility. ${ }^{18}$ More recently, Judge Wolfrum, in a declaration to the judgment of the ITLOS in Bangladesh/Myanmar, observed,

Further objectives to be taken into consideration by international courts and tribunals are to provide for transparency and predictability of the whole process. The ensuing international case law constitutes an acquis judiciaire, a source of international law to be read into articles 74 and 83 of the $\left[\right.$ LOSC]. ${ }^{19}$

Notwithstanding these claims, it is open to question whether the case law has been completely successful in this regard. In Libya/Malta, a number of judges engaged the Court's claim concerning the consistency and predictability of its decision in the case at hand. Judge Schwebel in his dissenting opinion, while acknowledging that there remained 'considerable room for differences of opinion in the application of equitable principles to problems of maritime delimitation,' submitted that

15 Guillaume, n. $2 . \quad{ }^{16}$ Ibid. $\quad{ }^{17}$ Ibid. $\quad{ }^{18}$ Ibid.

19 Delimitation of the Maritime Boundary in the Bay of Bengal (Bangladesh/Myanmar), Judgment of 14 March 2012, [2012] ITLOS Rep. 4, Declaration of Judge Wolfrum, 2. In the subsequent arbitration between Bangladesh and India, under the presidency of Wolfrum, the reference to the significance of the acquis judiciaire was included in the Award (In the Matter of the Bay of Bengal Maritime Boundary (Bangladesh v. India) [2014] PCA Case 2010-16, [339]. The authors would like to thank Nigel Bankes for drawing their attention to this point. 
the Court's cryptic references to the length of coasts, the distance between coasts, the sparsity of basepoints, and the general geographical context, suffice to justify the selection of the line of delimitation which it has chosen in this case. Nor do these arrested allusions conduce towards building the sense of consistency and predictability at which the Court and the law so rightly aim. ${ }^{20}$

Some of the recent academic literature also continues to voice doubt about the predictability and consistency of the case law. ${ }^{21}$

In the light of these different views concerning the consistency and predictability of the case law, the current volume is intended to further investigate that issue. To that end, the authors of individual chapters will assess to what extent the case law has been consistent in defining the relevant concepts and applying them to the specific case or not.

Contributors were initially requested to focus on the case law of the first two decades of the present century and to consider the previous case law to the extent this would provide the necessary context for understanding the more recent case law. During the first two decades of the present century, the case law has adopted the so-called three-stage approach to the delimitation of the continental shelf and the exclusive economic zone, which consists of first determining a provisional line, then assessing the need to adjust this line in the light of the relevant circumstances and finally carrying out the so-called proportionality test. ${ }^{22}$ There were two reasons for this proposing focus. First, this recent case law has received less scholarly attention than the older case law. Second, the existence of a common

${ }^{20}$ Libya/Malta, n. 13, Dissenting Opinion of Judge Schwebel, [1985] ICJ Rep., 172, 187. Similar criticisms were voiced by judges Ruda, Bedjaoui, and Jiménez de Aréchaga (ibid., Separate Opinion of Judges Ruda, Bedjaoui and Jiménez de Aréchaga, 76, 90 [37]), Mosler (ibid., Dissenting Opinion of Judge Mosler, 114, 114-115), and Judge ad hoc Valticos (ibid., Separate Opinion of Judge Valticos, 104, 108 [13]).

${ }^{21}$ See e.g. M. D. Evans, 'Maritime Boundary Delimitation: Whatever Next?,' in J. Barrett and R. Barnes (eds.), Law of the Sea; UNCLOS as a Living Treaty (British Institute of International and Comparative Law 2016), 41, 78; Fietta and Cleverly, n. 10, 579; A. G. Oude Elferink, 'International Law and Negotiated and Adjudicated Maritime Boundaries: A Complex Relationship,' (2015) 58 German Yearbook of International Law; I. Scobbie, 'Tom Franck's Fairness,' (2002) 13 European Journal of International Law 909, 924.

22 The three-stage approach was already used in Libya/Malta and Jan Mayen (both situations involving the delimitation between opposite coasts) but not in Canada/France (which could be said to involve both adjacent and opposite coasts). The Court in Qatar/Bahrain for the first time took the position that equidistance also provided the provisional starting point in cases involving adjacent coasts. The authors of this chapter consider the latter case to be the starting point of the consistent application of the three-stage approach (Maritime Delimitation and Territorial Questions between Qatar and Bahrain (Qatar v. Bahrain) [2001] ICJ Rep., 91-92 [170] and 111 [230-232]. 
general approach to the delimitation of the continental shelf and the exclusive economic zone offers the opportunity to assess whether this general approach has been applied in a consistent and predictable manner across cases. However, further consideration of this matter led to the conclusion that it would be counterproductive only to consider the more recent case law in detail. Many concepts of maritime delimitation law have their origins in the earlier case law and cannot be properly understood without an in-depth discussion of that earlier case law.

The editors requested that individual authors, in writing their respective chapters, take into consideration three issues:

1. an analysis of the case law's definition(s) and the characteristics of the main concepts under consideration in the chapter - in this connection, contributors were also requested to consider whether it is possible to distinguish between the approach of the ICJ, the ITLOS and arbitral tribunals;

2. how the main concepts under consideration in the chapter have been applied to the individual case; and

3. an assessment as to how the approach of the case law to the concepts under consideration in the chapter relate to the ICJ's statement in Libya/Malta on consistency and predictability.

The choice for an edited volume was deliberate. Current academic practices make it next to impossible to prepare a book of this nature in the form of a monograph. Aside from this practical consideration, the editors hold that an edited volume has the advantage of providing room for different opinions. In particular, in the case of a controversial topic like the law on the delimitation of the continental shelf and the exclusive economic zone, there is a considerable advantage to considering such different views and presenting them to the reader to form her or his own opinion.

\subsection{Development of the Law on the Entitlement to and Delimitation of the Continental Shelf and the Exclusive Economic Zone}

The relevant rules contained in multilateral conventions and customary international law provide the point of departure for the judiciary in determining the content of that law in more detail while applying it to the individual case. Changes in these relevant rules may be one important factor in explaining the differences in approach to the delimitation process between individual cases. In looking at the development of the case law on the delimitation of the continental shelf and the exclusive economic zone 
it is necessary to take into account the development of the applicable law as contained in multilateral conventions and customary international law. First, as in any field of law, the specificity of the applicable law will have an impact on the judge or arbitrator in interpreting and applying that law to the specific case. Second, developments in the applicable law, which may make it less or more specific, may provide the judge or arbitrator with greater or lesser leeway in this respect. In the case of the delimitation of the continental shelf and the exclusive economic zone, two aspects of the applicable law are relevant in this connection. First, this obviously concerns the rules that are applicable to the delimitation of the continental shelf and the exclusive economic zone. Second, as will become apparent from what follows, the rules concerning the basis of entitlement of the continental shelf and the exclusive zone are also relevant in this respect.

From its inception, the case law on the delimitation of the continental shelf and the exclusive economic zone has considered the basis of entitlement to these zones pertinent to determining the content of the rules applicable to their delimitation. The 1969 judgment of the ICJ in North Sea Continental Shelf is the starting point of the case law on the delimitation of the continental shelf and the exclusive economic zone. At the time, the negotiations that eventually were to result in the LOSC were in an initial phase and the rules on the entitlement to these zones and their delimitation as they would be included in the LOSC did not have an impact on the Court's judgment. ${ }^{23}$ The Court was faced with the question whether

${ }^{23}$ As a matter of fact, the impact ran the other way. The Court's finding that the entitlement to the continental shelf is based on natural prolongation of the land territory (North Sea Continental Shelf, n. 11, 30 [40] and 54 [101]) was one of the arguments of the so-called broad margin states to support their view that the entitlement to the continental shelf should not be limited by the 200-nautical-mile limit, but extended to the outer edge of the continental margin (see e.g. A. G. Oude Elferink, 'Article 76 of the LOSC on the Definition of the Continental Shelf: Questions Concerning Its Interpretation from a Legal Perspective,' (2006) 21 International Journal of Marine and Coastal Law 269, 272-273). The Court's formulation of the rule on the delimitation of the continental shelf to the effect that 'delimitation is to be effected by agreement in accordance with equitable principles, and taking account of all the relevant circumstances' (North Sea Continental Shelf(Judgment), n. 11, 54 [101]) provided a group of states at UNCLOS III with an argument to reject the rule on delimitation with its reference to equidistance and special circumstances contained in Art. 6 of the Convention on the Continental Shelf. At the same time, archival material related to North Sea Continental Shelf suggests that the Court's approach to the applicable law may have been influenced by a wish to impact on the further development of the law of the sea under consideration at the United Nations (see A. G. Oude Elferink, The Delimitation of the Continental Shelf between Denmark, Germany and the Netherlands; Arguing Law, Practicing Politics? (Cambridge University Press Cambridge 2013) 244-245 and 325). 
or not the Convention on the Continental Shelf provided the applicable law between the parties. Denmark and the Netherlands maintained that either the Convention itself had become binding on Germany or that the Convention reflected customary international law. According to Denmark and the Netherlands, the Convention's rule on continental shelf entitlement, based on adjacency to the coast, implied that this entitlement was based on proximity to the coast. ${ }^{24}$ This distance-based basis of entitlement required that the rule of delimitation also had to be based in distance. ${ }^{25}$ Denmark and the Netherlands submitted that Article 6 of the Convention of the Continental Shelf, which refers to delimitation by the equidistance or median line ${ }^{26}$ and provides for the possibility of another boundary where this is justified by special circumstances, did indeed accord primacy to the distance-based rule of equidistance. In their view, special circumstances only allowed for limited departures from the equidistance line. ${ }^{27}$ The Court did not accept this reasoning. The Convention had not become binding on Germany and its rule of delimitation did not reflect customary law. ${ }^{28}$ The Court rejected that the notion of adjacency in the Convention equalled a distance-based entitlement to the continental shelf. ${ }^{29}$ Instead, the Court found that entitlement to the continental shelf was based on natural prolongation from the land territory of the coastal state. ${ }^{30}$ This finding implied that the equidistance method of delimitation was not directly linked to the basis of continental shelf entitlement. The Court did conclude that there was a linkage between entitlement to and delimitation of the continental shelf, observing that delimitation is to be effected [...] in such a way as to leave as much as possible to each party all those parts of the continental shelf that constitute a natural prolongation of its land territory into and under the sea, without encroachment on the natural prolongation of the land territory of the other.' ${ }^{31}$

Having rejected that equidistance constituted an obligatory rule under customary international law, the Court formulated what it considered to constitute the applicable law: 'delimitation is to be effected by agreement in accordance with equitable principles, and taking account of all the relevant circumstances. ${ }^{32}$ Although the Court's judgment provided the

${ }^{24}$ North Sea Continental Shelf (Judgment), n. 11, 30 [39]. $\quad{ }^{25}$ Ibid.

26 Technically speaking, the equidistance line and the median line are the same. Both lines are at equal distance from the baselines from which the breadth of the territorial of the states concerned is measured.

27 North Sea Continental Shelf(Judgment) [1969] ICJ Rep., 21 [13].

${ }^{28}$ Ibid., 25-28 [25-32]. $\quad{ }^{29}$ Ibid., 31-32 [41-42].

${ }^{30}$ Ibid., 32 [43]. $\quad{ }^{31}$ Ibid., 53 [101(C)(1)]. $\quad{ }^{32}$ Ibid. 
parties with some indications on how to apply this rule in their further negotiations on the delimitation of their continental shelf, the Court's customary rule cannot be said the have contributed significantly to the certainty and predictability of the law. The Court's refusal to consider the status of the combined rule of equidistance and special circumstance also implied continued uncertainty about the relationship between these two elements of Article 6. The Court's rejection of Article 6 as customary law implied that states and courts and tribunals in the future would be faced with two rules of law of different content, possibly resulting in different outcomes depending on the applicable law in the individual case.

The adoption of the LOSC implied a further and final development in the multilateral rules on the entitlement to and the delimitation of the continental shelf. Under the Convention, entitlement to the exclusive economic zone is based on distance from the coast, while entitlements to the continental shelf is based either on distance from the coast or natural prolongation. ${ }^{33}$ Like the exclusive economic zone, the continental shelf in any case extends to 200 nautical miles from the baselines, but it extends beyond that distance where the outer edge of the continental margin extends beyond that limit. ${ }^{34}$ Although Article 76 in its rules on the precise determination of the outer limits of the continental shelf beyond 200 nautical miles contains two references to distance from the coast, the entitlement to the continental shelf beyond 200 nautical miles otherwise is not linked to that criterion.

The implications of distance-based entitlement to the continental shelf within 200 nautical miles was first considered in Libya/Malta. The Court found that this basis of entitlement had to be reflected in 'the choice of the criterion and the method which it is to employ in the first place to arrive at a provisional [delimitation line]. ${ }^{35}$ On that basis, the Court adopted an equidistance line as the provisional line of delimitation. ${ }^{36} \mathrm{~A}$ first detailed assessment of the relationship between the basis of continental shelf entitlement beyond 200 nautical miles and the delimitation of that part of the shelf was carried out by the ITLOS in its 2012 judgment in Bangladesh/Myanmar. ${ }^{37}$

The LOSC's rule on the delimitation of the exclusive economic zone and the continental shelf contained in its substantively identical Articles 74 and 83 is a compromise that was intended to bridge the insuperable divide between the states at UNCLOS III supporting the rule contained

\footnotetext{
33 LOSC, Arts. 57 and 76. $\quad{ }^{34}$ LOSC, Art. 76(1). $\quad{ }^{35}$ Libya/Malta, n. 13, 46-47 [61].

36 Ibid., 46-47 [60-62]. $\quad 37$ Bangladesh/Myanmar, n. 19, [397-423].
} 
in the Convention on the Continental Shelf and those supporting the rule formulated by the ICJ in North Sea Continental Shelf. ${ }^{38}$ As a consequence, the judiciary was left with the task of seeking to find an approach to the delimitation of the exclusive economic zone and the continental shelf that ideally should reflect the compromise solution contained in Articles 74 and 83 , while at the same time delimiting those boundaries on the basis of a reasoned decision.

How the development of the applicable law relating to entitlement to and delimitation of the exclusive economic zone and the continental shelf has been addressed in the case law will in particular be considered in more detail in Chapters 3, 6, and 13 of this volume.

\subsection{Third-Party Dispute Settlement and the Law of Maritime Delimitation $^{39}$}

Disputes between states can only be submitted to third-party dispute settlement with the consent of the parties. That consent may either have been given previously under an instrument of general application, or by an agreement between the parties to submit a specific dispute to third-party dispute settlement. Disputes concerning the delimitation of the continental shelf and the exclusive economic zone have been submitted to courts and tribunals through both of these options. The present section briefly outlines the availability of dispute settlement provisions in multilateral instruments on the law of the sea and beyond, and the options that states have used to submit their delimitation disputes to third-party settlement. The section also compares the trends in settlement of delimitation disputes through negotiations and third-party settlement.

The Convention on the Continental Shelf does not contain a provision on third-party settlement. The International Law Commission (ILC), which prepared draft articles on the law of the sea in the 1950s, had provided for this option. As a matter of fact, this proposal originated in a debate on the delimitation provision for the continental shelf. During the 1951 session of the ILC, Scelle had proposed that:

38 See further e.g. S. N. Nandan and S. Rosenne (eds.), United Nations Convention on the Law of the Sea 1982: A Commentary, vol. 2 (Martinus Nijhoff Dordrecht 1993), 796-816 and 948-985.

39 A part of this section is based on A. G. Oude Elferink, 'International Law and Negotiated and Adjudicated Maritime Boundaries: A Complex Relationship,' (2015) 58 German Yearbook of International Law 231, 234-238. 
the Commission should state that, if two governments could not reach agreement as to the partition of the continental shelf, neither State was entitled to exploit it. They must either maintain the status quo or they would be under an obligation to refer the question to the International Court of Justice. $^{40}$

This led the ILC to adopt a draft article providing for arbitration where states could not agree on the delimitation of their continental shelf. ${ }^{41}$ Subsequently, the scope of this provision was extended to the continental shelf regime as a whole. ${ }^{42}$ The 1956 ILC draft articles that formed the basis of discussion at the 1958 United Nations Conference on the Law of the Sea (UNCLOS I) provided for referral to the ICJ. ${ }^{43}$ However, the Conference rejected the possibility of compulsory dispute settlement in relation to the regime of the continental shelf.

The Conference's rejection of a dispute settlement clause did not imply that the delimitation of the continental shelf was altogether beyond the reach of compulsory dispute settlement for prospective parties to the Convention on the Continental Shelf. The 1958 Conference itself adopted the Optional Protocol of signature concerning the compulsory settlement of disputes. Other instruments, such as the ICJ Statute with its optional clause jurisdiction, the Pact of Bogotá ${ }^{44}$ and bilateral treaties on dispute settlement, also provided a basis for unilateral recourse to third-party settlement.

The possibility of judicial settlement of maritime boundaries where negotiations would fail to achieve an agreement was again considered at UNCLOS III. It was considered that the content of the substantive delimitation provision was closely related to the regime of compulsory dispute settlement and that they should be treated as one package. ${ }^{45}$ The outcome of the negotiations as contained in Articles 74 and 83 of the LOSC explicitly recognizes that negotiations may not lead to an agreement. Common Paragraph 2 provides that ' $\mathrm{i}] \mathrm{f}$ no agreement can be reached within a reasonable period of time, the states concerned shall resort to the procedures provided for in Part XV.' At the same time, this reference does not imply

40 Yearbook of the International Law Commission, 1951, vol. I, 288, [5]; see also ibid., 292, [65].

41 See ibid., 293-294, [100-101]. $\quad 42$ See ibid., 1953, vol. II, 213 and 216-217.

43 See ibid., 1956, vol. II, 300.

44 American Treaty on Pacific Settlement, signed 30 April 1948, entered into force 6 May 1949, 30 UNTS 449.

45 See further A. G. Oude Elferink, The Law of Maritime Boundary Delimitation: A Case Study of the Russian Federation (Martinus Nijhoff Dordrecht 1994) 27-28. 
that third-party settlement will always be available to states parties to the Convention to settle their disputes concerning the delimitation of the continental shelf and the exclusive economic zone. First, Section 1 of Part XV imposes a number of procedural hurdles. As Article 279 indicates, Part XV is applicable to disputes concerning the interpretation or application of the LOSC. Maritime delimitation disputes may also involve disputes concerning the sovereignty over land territory or land boundaries. ${ }^{46}$ However, such mixed disputes may be submitted to third-party settlement under other instruments, with the LOSC still providing part of the applicable law. ${ }^{47}$ Further procedural requirements are contained in Articles 281, 282, and 283 of the LOSC. As a result of Articles 281 and 282 a dispute concerning the delimitation of maritime boundaries may be excluded from the compulsory procedures contained in Section 2 of Part XV. Article 282 implies that the procedures of Part XV do not apply where the parties to a dispute have agreed to settle it through a procedure entailing a binding decision under another agreement. Article 282 does not limit the possibility to settle delimitation disputes through third-party settlement, but does limit the recourse to Section 2 of Part XV. ${ }^{48}$ The implications of Article 282 have been considered by the ICJ in its decision on preliminary objections in Somalia v. Kenya. ${ }^{49}$ This concerned the effect of an optional clause

46 Admittedly, different views exist over the question to what extent a court or tribunal could deal with all aspects of a mixed dispute that is submitted under the LOSC (for an overview see e.g. I. Buga, 'Territorial Sovereignty Issues in Maritime Disputes: A Jurisdictional Dilemma for Law of the Sea Tribunals,' (2012) 59 International Journal of Marine and Coastal Law 27). It would seem that a court or tribunal in any case would be excluded from dealing with matters concerning the sovereignty over territory to the extent this would imply a ruling on a claim that does not arise directly under the LOSC (see also ITLOS Dispute concerning the MOX Plant, International Movements of Radioactive Materials, and the Protection of the Marine Environment of the Irish Sea (Ireland v. United Kingdom), Order No. 3 of 24 June 2003, [19]; In the Matter of the Arctic Sunrise Arbitration (Netherlands v. Russia), Award on the Merits, 14 August 2015, [192].

47 An example in this respect is Territorial and Maritime Dispute between Nicaragua and Honduras in the Caribbean Sea (Nicaragua v. Honduras) [2007] ICJ Rep. 659. Nicaragua submitted this case unilaterally to the ICJ under the Pact of Bogotá. The case involved a sovereignty dispute over islands and the delimitation of the maritime boundary. The LOSC provided the applicable law for the latter matter.

48 See also Maritime Delimitation in the Indian Ocean (Somalia v. Kenya), Judgment of 2 February 2017, [130].

${ }^{49}$ For a discussion of the judgment, see also N. Bankes, 'The Relationship between Declarations under the Optional Clause of the Statute of the International Court of Justice and Part XV of the Law of the Sea Convention' (K. G. Jebsen Centre for the Law of the Sea blog, available at http://site.uit.no/jclos/files/2017/02/The-relationship-betweendeclarations-under-the-optional-clause-of-the-Statute-of-the-International-Court-ofJustice-and-Part-XV-of-the-Law-of-the-Sea-Convention.pdf). The only other instance in which Art. 282 was considered is Barbados v. Trinidad and Tobago, where the tribunal 
declaration under Article 36 of the Court's Statute containing a reservation. The parties were in agreement that optional clause declarations without a reservation constituted an agreement in the sense of Article 282. ${ }^{50}$ The Court concurred, observing that the reference to 'otherwise' in Article 282 was 'broad enough to encompass an agreement to the jurisdiction of this Court that is expressed in optional clause declarations. ${ }^{51}$ However, the Kenyan optional clause declaration excluded disputes in regard to which the parties to the dispute have agreed or shall agree to have recourse to some other method or methods of settlement. ${ }^{52}$ Kenya submitted that Section 2 of Part XV of the LOSC constituted such an agreement. ${ }^{53}$ The Court did not accept this point of view, observing among others that the drafters of Article 282 intended to include optional clause declarations in its scope of application. In that light, the Court considered it unlikely that the drafters would have wanted to exclude the more than half of the declarations that at the time included a reservation. ${ }^{54}$ The Court also observed that Kenya's position would achieve exactly the opposite of what Article 282 was intended to do. Instead of giving priority to Article 282 procedures, Kenya's position would give priority to Section 2 of Part XV of the LOSC. ${ }^{55}$ Finally, the Court found that declining jurisdiction might mean that there would not be a dispute settlement procedure available. In this connection, the Court referred to Article 286 of the LOSC, which provides that procedures under Section 2 are available subject to Section 3 on limitations and exceptions to the applicability of Section $2 .{ }^{56}$ The Court's interpretation of Article 282 thus ensures the availability of compulsory dispute settlement in accordance with that article for disputes concerning the interpretation or application of the LOSC even in case a state has made a declaration under Article 298 of the LOSC, which may also pertain to the delimitation of maritime boundaries.

Article 281 provides that recourse to compulsory dispute settlement is excluded when parties have agreed on another means to settle their dispute and that agreement, in case of failure of that means, does not exclude recourse to other procedures. Article 281 has been considered in one case concerning the delimitation of maritime boundaries. In Barbados v. Trinidad and Tobago, the arbitral tribunal observed that it would appear that Article 281 is intended primarily to cover the situation where the

limits itself to noting that it is not applicable (Arbitration between Barbados and Trinidad and Tobago [2006] 27 RIAA 147 (Award), [200(iii)]).

50 Somalia v. Kenya, n. 48, [110-111].

${ }^{51}$ Ibid., [126]. The Court found that this conclusion was supported by the drafting history of Art. 282 (ibid., [127].

52 Ibid., [31]. $\quad{ }^{53}$ Ibid., [110]. $\quad{ }^{54}$ Ibid., [129]. $\quad{ }^{55}$ Ibid., [130]. $\quad{ }^{56}$ Ibid., [132]. 
Parties have come to an ad hoc agreement as to the means to be adopted to settle the particular dispute which has arisen. ${ }^{57}$ The Tribunal then pointed out that in the present case the parties had agreed to settle their dispute through negotiations, but that this was not done through a formal agreement. The tribunal concluded '[s]ince their de facto agreement did not exclude any further procedures, and since their chosen peaceful settlement procedure - negotiations - failed to result in a settlement of their dispute' Article 281 did not exclude recourse to third-party settlement under Section 2 of Part XV of the LOSC. ${ }^{58}$ The award does not contain any reference to the award on jurisdiction in Southern Bluefin. That award provides a much more detailed discussion of Article 281, and its findings seemingly contradict those of the award in Barbados $v$. Trinidad and Tobago on two points. First, the award in Southern Bluefin does not indicate that Article 281 is primarily intended to cover ad hoc agreements. The award was concerned with implications of a dispute settlement provision contained in the Convention for the Conservation of Southern Bluefin Tuna, ${ }^{59}$ which sets up a regime for the management of southern Bluefin tuna, for Article 281 of the LOSC. Second, the award found that the exclusion of recourse to further procedures need not be explicitly mentioned in the agreement concerned. ${ }^{60}$ This point is not considered by the award in Barbados v. Trinidad and Tobago. The implications of Article 281 more recently have been considered by the tribunal in Philippines $v$. China. In its award on jurisdiction the tribunal departed from Southern Bluefin Tuna, finding that Article 281 implied that the exclusion of further procedures should be explicitly mentioned in the agreement concerned. ${ }^{61}$ Depending on the approach that will be followed in future cases, the impact of Article 281 on the availability of third-party settlement of maritime boundaries may vary considerably.

Article 283 of the LOSC requires parties to exchange views when a dispute arises. In view of the fact that delimitation disputes generally will have been subject to negotiations, Article 283 does not seem to place an additional hurdle before a state can submit a delimitation dispute to thirdparty settlement. This submission is based on the findings of the tribunal in Barbados v. Trinidad and Tobago, which held that:

\footnotetext{
57 Ibid., [200(ii)]. $\quad{ }^{58}$ Ibid.

59 Convention for the Conservation of Southern Bluefin Tuna, signed 10 May 1993, entered into force 20 May 1994, 1819 UNTS 360.

60 Southern Bluefin Tuna Cases (Award).

61 Philippines v. China (Award of 12 July 2016), [223-225].
} 
Article 283(1) cannot reasonably be interpreted to require that, when several years of negotiations have already failed to resolve a dispute, the Parties should embark upon further and separate exchanges of views regarding its settlement by negotiation. The requirement of Article 283(1) for settlement by negotiation is, in relation to Articles 74 and 83, subsumed within the negotiations which those Articles require to have already taken place. ${ }^{62}$

The absence of a requirement to have separate recourse to Article 283, implies that states will not be 'put on notice' by a negotiating partner that they consider that negotiations in their view have been exhausted. states thus cannot use such 'advance notice' to make a declaration under Article 298 of the LOSC to prevent recourse to third-party settlement, where they have not yet done so.

Article 298 of the Convention allows states parties to exclude disputes concerning the interpretation or application of Articles 74 and 83 (and Article 15 on the delimitation of the territorial sea) from the Convention's provisions on compulsory dispute settlement. ${ }^{63}$ Only 25 of the 167 states parties to the LOSC currently have used this option. ${ }^{64}$ However, the reach of these declarations is much broader than the twenty-five states concerned, as it also affects their neighbours. Interestingly, more than half (thirteen) of the declarations presently in force have been made subsequent to the state concerned becoming a party to the Convention. ${ }^{65}$

${ }^{62}$ Barbados v. Trinidad and Tobago, n. 49, [202]. The Tribunal also held that there was no obligation to exchange views on other peaceful means of settlement (ibid.). The Tribunal reached a similar conclusion in respect of Art. 283(2) (see ibid., [205]; see also ibid., [206]). For a recent and detailed discussion on the implications of Art. 283 of the LOSC see The Matter of the Chagos Marine Protected Area Arbitration between the Republic of Mauritius and the United Kingdom of Great Britain and Northern Ireland, Award of 18 March 2015, [351-386].

${ }^{63}$ LOSC, Art. 298(1)(a)(i). Art. 298 envisages that delimitation disputes that are covered by a declaration excluding third-party settlement may be submitted to conciliation in accordance with Annex $v$. to the LOSC. This procedure only recently has been used for the first time by East Timor in relation to a delimitation dispute with Australia (see Timor-Leste's Conciliation with Australia on Maritime Boundaries; available at http://timor-leste.gov.tl/ wp-content/uploads/2016/04/15398-FACT-SHEET-CONCILIATION.pdf). On the role of other modes of third-party dispute settlement in relation to delimitation disputes see also Oude Elferink, n. 39.

${ }^{64}$ This figure is based on the information contained on the relevant page of the website of the Treaty Section of the Office of Legal Affairs of the United Nations (available at http:// treaties.un.org/Pages/Treaties.aspx?id=21\&subid=0\&lang=en\&clang=_en). In addition, a limited number of states have indicated that they only accept a specific means of compulsory dispute settlement for these types of disputes (ibid.).

65 Ibid. In addition, Ghana had made a declaration to this effect on 15 December 2009 but subsequently withdrew that declaration on 22 September 2014 (ibid., n. 18). 
Possibly, some of these subsequent declarations may have been triggered by the way in which courts and tribunals have been dealing with the interpretation and application of Articles 74 and 83 of the LOSC.

The possibility of unilateral recourse to third-party dispute settlement under the LOSC seems to have contributed significantly to the use of compulsory dispute settlement mechanisms. Since the entry into force of the LOSC in 1994, five maritime delimitation cases have been brought unilaterally under Part XV of the LOSC. During this same period, nine cases were submitted jointly or unilaterally under other instruments. Recourse to the option of unilateral submission of delimitation disputes under the LOSC reflects a broader trend. While until 1988 there had only been one, unsuccessful, attempt by Greece to settle its continental shelf boundaries with Turkey by unilateral recourse to the ICJ, since 1988, fourteen maritime delimitation cases were started unilaterally. ${ }^{66}$ By way of comparison, for the same periods the figures for joint submissions are respectively ten and four. ${ }^{67}$ Whether this trend will continue will depend, among other factors, on whether or not states will close the possibilities of recourse to this avenue for their neighbours by for instance making a declaration under Article 298(1)(a)(i) of the LOSC or withdrawing or varying their optional clause declaration under Article 36(2) of the Statute of the ICJ.

Third-party settlement may both involve recourse to a standing body in this case the ICJ and the ITLOS - and ad hoc arbitration. Figure 1.1 provides an overview of recourse to these two modes of dispute settlement over time. As Figure 1.1 indicates, cases have been referred to standing bodies somewhat more often than to ad hoc arbitration. However, in this connection it should not be lost from view that two cases that initially were submitted to ad hoc arbitration (Bangladesh/Myanmar and Ghana/Côte d'Ivoire) were subsequently transferred to the ITLOS. If these two cases are included in the category of ad hoc arbitration instead of the category of standing courts, the figures for the two categories are closer, being respectively thirteen and sixteen. Figure 1.1 does not suggest that the preference for one or the other mode of dispute settlement has shifted significantly over time. The current project did not make a detailed assessment as to why states opt for arbitration or a standing court. ${ }^{68}$ In the case of

66 The possibility that a state may unilaterally submit a dispute to a court or tribunal may also induce states to seek to agree on joint submission (for an example see Oude Elferink, n. 23, 175).

${ }^{67}$ See Table 1.1 at the end of this chapter.

${ }^{68}$ For a discussion of the merits and drawbacks of standing courts and ad hoc tribunals, see J. G. Merrills, International Dispute Settlement, 5th ed. (Cambridge University Press 


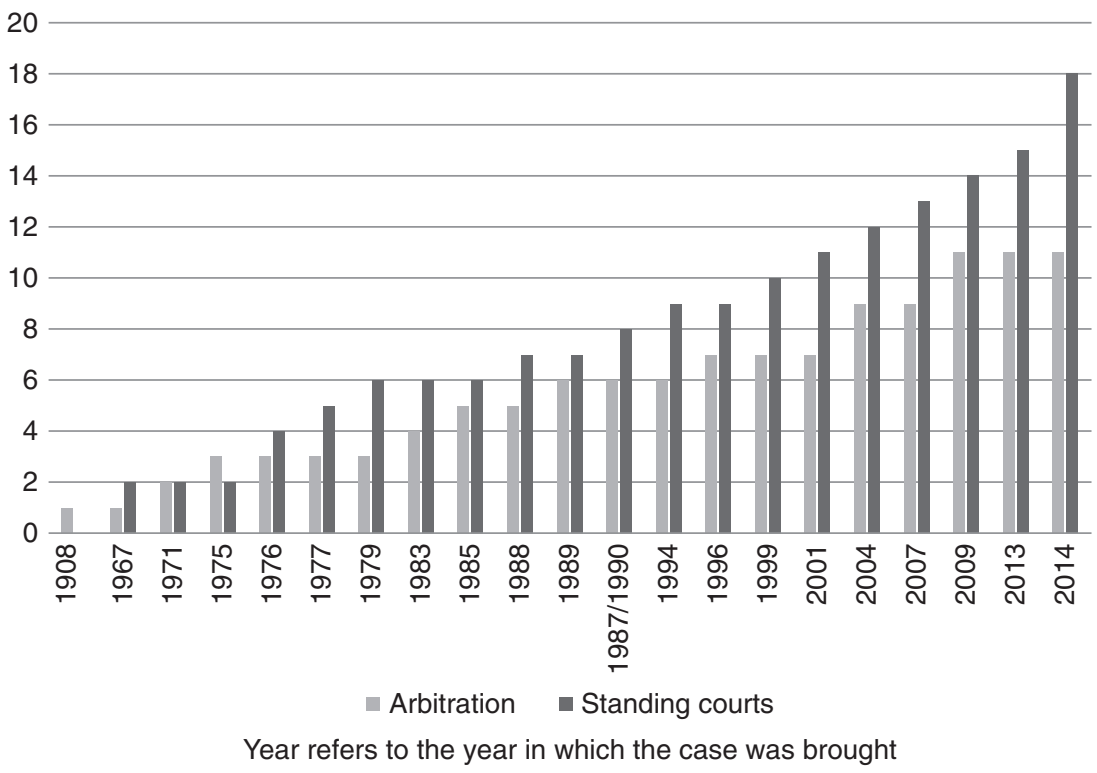

Figures are cumulative

Figure 1.1 Use of ad hoc arbitration and standing courts

unilateral applications, the availability of a specific forum, like the ICJ under the Pact of Bogotá or Annex VII arbitration as the default mechanism under Part XV of the LOSC, provides a logical explanation. The additional costs involved in arbitration seem a likely explanation why two cases that were started unilaterally as Annex VII arbitrations were subsequently transferred to the ITLOS. The chapters in this volume will consider the decisions of the ICJ, the ITLOS, and arbitral tribunals, which should allow determining whether standing courts differ significantly from ad hoc tribunals as regards their handling of the applicable law and its application to the individual case. A difference in that regard might be a factor that explains why states opt for a specific dispute settlement body.

To get a proper perspective on the significance of the case law for settling maritime boundaries, a brief comparison to negotiated settlements can be made. Notwithstanding the recurrent use of compulsory dispute settlement mechanisms, negotiations remain the primary mode for dealing with the delimitation of maritime boundaries between neighbouring states. A review of the period 2003-2014 by the authors in the preparation

Cambridge 2011), 111-115, 161-166; C. H. Brower, 'Arbitration,' in Max Planck Encyclopedia of Public International Law, online ed. (last updated February 2007) [91]. 
of this chapter identified fifty-five agreements related to the delimitation of maritime zones. ${ }^{69}$ By way of comparison, in the same period eleven cases were submitted to compulsory dispute settlement procedures. ${ }^{70} \mathrm{~A}$ comparison with earlier figures suggests a somewhat increased role for third-party settlement. A study from 1990 lists 154 maritime boundaries that had been settled between 1925 and $1990 .{ }^{71}$ Ten boundaries, or some 6.5 per cent of this total, had been settled by adjudication. For the period 2003-2014 the share of adjudicated boundaries in the total is 16.7 per cent. $^{72}$

A major, perhaps even the most important, difference between negotiated and adjudicated settlements may be that cases with a complex legal setting will more often end up in court. One measure to determine this complexity is the method of delimitation that has been used to determine the boundary. Already in North Sea Continental Shelf, in which the ICJ found that equidistance did not constitute an obligatory method for the parties, the Court emphasized the advantages of the equidistance method in geographically - and hence legally - straightforward situations. ${ }^{73}$ This same distinction has been observed by Legault and Hankey in a statistical analysis of negotiated boundaries. ${ }^{74}$ Eighty-nine per cent of the boundaries between opposite coasts included in their sample are based on the equidistance method. On the other hand, only 40 per cent of the cases in their sample involving adjacent coasts employ the equidistance method. In the latter case this figure was split evenly between strict equidistance and modified equidistance. ${ }^{75}$ Interestingly, the figures for adjudicated

${ }^{69}$ Based on a review of Law of the Sea Bulletins nos. 53-89 and C. Lathrop (ed.), International Maritime Boundaries, online ed., including the 2015 update (Martinus Nijhoff). Because some delimitation agreements are not in the public domain immediately after their conclusion, it should not be excluded that the actual figure is higher than fifty-five. The fifty-five agreements concerned also include two agreements on a joint zone and a number of agreements determining tripoints or transforming a continental shelf boundary into a single maritime boundary.

${ }^{70}$ See Table 1.1 at the end of this chapter.

${ }^{71}$ R. W. Smith (ed.), Maritime Boundaries of the World, Limits in the Seas 108, 1st revision (US Department of State Washington, DC 1990) 3 and 5.

72 Based on the number of cases that were submitted to a court or tribunal in this period (see Table 1.1 at the end of this chapter).

${ }^{73}$ North Sea Continental Shelf, n. 11, 37, [57].

74 A recent review in this respect is contained in T. Cottier, n. 10, 242-250. However, Cottier focusses on the period between 1942 and 1992 (ibid., 242), which is basically the period covered by Legault and Hankey. Unsurprisingly, Cottier conclude that his findings are 'roughly appropriate' when compared to the study of Legault and Hankey (ibid., 249).

75 H. Legault and B. Hankey, 'Method, Oppositeness and Adjacency, and Proportionality in Maritime Boundary Delimitation,' in J. I. Charney and L. M. Alexander (eds.), International Maritime Boundaries, vol. 1 (Martinus Nijhoff Dordrecht 1991), 203, 215-216. 
boundaries indicate a larger reliance on the equidistance method than is the case for negotiated boundaries involving adjacent coasts. Eleven out of twenty adjudicated boundaries, or 55 per cent, delimiting the continental shelf and/or the exclusive economic zone use the equidistance method. ${ }^{76}$ This might suggest that the legal complexity of a delimitation is not the only factor explaining why states resort to adjudication. However, before turning to other explanations, the figure of 55 per cent requires some qualification. Only three out of these eleven cases - 15 per cent of the total number of adjudicated cases - concern strict equidistance for (almost) the entire boundary. ${ }^{77}$ In addition, modified equidistance lines at times may have little relationship to the strict equidistance line. In this case, use of the term modified equidistance line might be taken to suggest the absence of a complex legal and geographical situation, while the opposite may be true.

\subsection{The Composition of the Bench and the Impact of External Criticism: Tunisia/Libya and Libya/Malta}

People will have different views on the law. Judges are no exception. The 1969 judgment in North Sea Continental Shelf was adopted by an eleven to six vote. Not unsurprisingly, the opinions of a number of the dissenting judges indicate that they did not agree with the majority on the role of equidistance in the delimitation process. This existence of different views on the bench raises the question whether developments in the case law on maritime delimitation may (in part) be explained by changes in the composition of third-party dispute settlement bodies. Although this is a topic that because of its breadth and complexity is beyond the scope of the present volume, this section intends to provide the reader with some ideas as to how the composition of the bench and external criticism may impact on the consistency and predictability of the case law. Instead of looking at the case law as a whole, this section opts for the rather more manageable task of comparing the judgments on the merits in Tunisia/Libya and Libya/Malta with a focus on the latter case. As was noted above, in 2001 then ICJ President Gilbert Guillaume submitted that the unpredictability of Tunisia/Libya had led to doubts whether there still existed a law of maritime delimitation. He identified Libya/Malta as a first step towards predictability. Guillaume also submitted that this development was due

76 This concerns entries A.8, A.12, A.13, B.2, B.3, B. 6, B.7, B.8, B.9, B.10, and B. 11 in Table 1.1 at the end of this chapter. In making this count, only boundaries that were established de novo by a court or tribunal have been taken into account.

77 This concerns entries B.3, B.7, and B.8 in Table 1.1 at the end of this chapter. 
to criticism from beyond the bench. ${ }^{78}$ This section will seek to establish whether there are traces in the judgment and the opinions in Libya/Malta to substantiate these positions. ${ }^{79}$

In both Tunisia/Libya and Libya/Malta the judgment on the merits was supported by a clear majority of respectively ten to four and fourteen to three. The composition of the Court in both cases differed to some extent. Eleven of the judges participating in Tunisia/Libya also participated in Libya/Malta and the majority in both cases was largely included the same judges. Eight judges were part of the majority in both cases. ${ }^{80}$ The majority in Libya/Malta also included six judges who were not on the bench in Tunisia/Libya.

Judges Schwebel and Mosler, who were part of the majority in Tunisia/Libya, dissented in Libya/Malta. While Schwebel and Mosler both commend the judgment in Libya/Malta for taking the median line as a starting point, they criticize the judgment because it does not lead to greater predictability. ${ }^{81}$ The individual opinions of judges voting with the majority in Libya/Malta indicate differing appreciations of the judgment. Judge El-Khani's declaration indicates that he does not agree with the approach of the judgment. His argument that the outcome should have given greater weight to proportionality, which would have been in agreement with equity, suggests that he did not support the use of the median line as a starting point. ${ }^{82}$ Sette-Camara, while supporting the use of equidistance as a provisional starting point, rejects one of the Court's main argument for taking this approach, namely that entitlement to the shelf is based on distance, requiring a delimitation method that is also based in distance. ${ }^{83}$ The linkage between entitlement and delimitation is one way of achieving greater predictability in the applicable law. As the

${ }^{78}$ For both points, see above Section 1.2. In addition to Tunisia/Libya, Guillaume also referred to Gulf of Maine in his speech. As this case was not decided by the full Court, but a five-member Chamber, Gulf of Maine is considered less appropriate for the current comparative exercise (Case concerning the Continental Shelf (Tunisia/Libyan Arab Jamahiriya) [1982] ICJ Rep. 18; Delimitation of the Maritime Boundary in the Gulf of Maine Area (Canada/United States) [1984] ICJ Rep. 246).

79 It is acknowledged that the judgment and opinions do not provide a full view on the factors impacting on the internal decision-making process of the Court. However, they are the only readily available sources.

80 This concerns Elias, Lachs, Morozov, Nagendra Singh, Ago, Sette-Camara, El-Khani, and Jiménez de Aréchaga.

${ }^{81}$ Libya/Malta, n. 13, Dissenting Opinion of Judge Schwebel, 186-187; ibid., Dissenting Opinion of Judge Mosler, 114.

82 Ibid., Declaration of Judge El-Khani, 59.

${ }^{83}$ Ibid., Separate Opinion of Vice-President Sette-Camara, 71. 
Court indicated itself, it 'seems logical to the Court that the choice of the criterion and the method which it is to employ in the first place to arrive at a provisional result should be made in a manner Consistent with the concepts underlying the attribution of legal title. ${ }^{84}$ Otherwise, Sette-Camara stresses the importance of reaching an equitable solution. ${ }^{85}$

At its outset, the joint separate opinion of judges Ruda, Bedjaoui, and judge ad hoc Jiménez de Aréchaga in Libya/Malta seems to support the judgment's approach, noting that they agree with the Court's exposition of the applicable law and the Court's reasoning in selecting the delimitation line and adjusting the provisional median line. ${ }^{86}$ However, their subsequent argument that the provisional delimitation line should have been shifted further north because this would have divided the area of overlapping claims in equal parts and would have better reflected the difference in length of the relevant coasts, ${ }^{87}$ indicates that their solution is completely divorced from the two-stage approach of the Court. The solution of Ruda, Bedjaoui and Jiménez de Aréchaga as a matter of fact makes the determination of a provisional line superfluous as their final line results from two factors that operate independently of this line. The opinion of judge ad hoc Valticos does indicate support for the approach of the judgment because of the role it accords to equidistance and the fact this approach is preferable to other approaches. ${ }^{88}$ In view of Valticos's opinion as a whole, it seems likely that he is referring to other approaches that are less structured.

The joint opinion of Ruda, Bedjaoui and Jiménez de Aréchaga in Libya/Malta is the only opinion that contains a reference to academic criticism of the previous judgments of the Court. However, this does not concern criticisms of the unpredictability of the Court, but rather refers to literature that considers that too little weight has been given to the factor of proportionality. ${ }^{89}$

This brief review of the judgment and individual opinions in Libya/Malta allows making a number of tentative conclusions. First, the judgment in Libya/Malta does refer to the need for consistency and a

${ }^{84}$ Ibid., 46, [61].

${ }^{85}$ Ibid., Separate Opinion of Vice-President Sette-Camara, 75.

${ }^{86}$ Ibid., Joint Separate Opinion Judges Ruda and Bedjaoui and Judge ad hoc Jiménez de Aréchaga 76, [1].

${ }^{87}$ Ibid., 89-91, [35-38].

${ }^{88}$ Ibid., Separate Opinion of Judge ad hoc Valticos 106-108 [7-13] and 111 [22].

${ }^{89}$ Ibid., Joint Separate Opinion Judges Ruda and Bedjaoui and Judge ad hoc Jiménez de Aréchaga 85, [23]. 
degree of predictability in judicial decisions. This reference suggests that the majority considered that this was an issue of concern. A number of opinion's share this concern, but other opinions rather indicate that they support an equity-based approach that does not accord specific weight to the equidistance method. The opinion of Ruda, Bedjaoui and Jiménez de Aréchaga confirms that criticism from beyond the bench may impact on the internal decision making of the Court.

The fact that the majority in Tunisia/Libya and Libya/Malta to a considerable extent consisted of the same judges might indicate that the thinking of the majority about the approach to delimitation did change between 1982 and 1985. The fact that the majority in Libya/Malta included six judges that were not on the bench in 1982 may also have contributed to the difference in approach.

Finally, one highly significant difference between the two cases are the facts. As the judgment in Libya/Malta also acknowledges, in cases involving opposite coasts, the Court had already recognized the equitable nature of equidistance in North Sea Continental Shelf. ${ }^{90}$ In the end, this latter circumstance may have played a larger role in adopting a provisional equidistance line than the perceived need for consistency and a degree of predictability. Still, if the Court would have been true to its approach in Tunisia/Libya it could also have weighed up the relevant circumstances to immediately arrive at the final delimitation line, an approach that was effectively advocated in the joint separate opinion of judges Ruda, Bedjaoui and Jiménez de Aréchaga in Libya/Malta, but was not adopted by the majority.

\subsection{Introduction of the Chapters of the Project}

The rest of this volume consists of twelve substantive chapters and a final chapter that will draw together the conclusions of these individual chapters. This section briefly introduces these chapters. Chapter 2 of this volume is concerned with the delimitation of the territorial sea and in particular seeks to determine in which respects the regime of the territorial sea and its delimitation differ from that of the zones beyond the territorial sea. This chapter is included because it is considered that an analysis of the case law on the delimitation of the territorial sea may enhance our understanding of the case law on the delimitation of the continental shelf and the exclusive economic zone.

\footnotetext{
90 North Sea Continental Shelf, n. 11, [62].
} 
The actual discussion of the case law on the delimitation of these latter zones starts off with Chapter 3, which addresses the relationship between the entitlement to the continental shelf and the exclusive economic zones and their delimitation, which was briefly introduced in Section 1.3 above. As the case law indicates, the basis of entitlement is one of the critical factors impacting on the development of delimitation law. Chapter 4 deals with the law applicable to these zones as formulated in general terms in the Convention on the Continental Shelf, the LOSC, and customary international law. The existence of these three sources of law also raises the question to which extent they differ or are similar in content.

Chapter 5 looks at the case law in relation to provisional arrangements as defined in Articles 74(3) and 83(3) of the LOSC and provisional measures that may be prescribed by courts and tribunals pending their decision on the merits. The relevant case law indicates that there are significant linkages between these two topics, which Chapter 5 explores. Chapter 6 considers the role of equity, equitable principles, and the equitable solution in the law of maritime delimitation. The ICJ accorded equity and equitable principles a central role in the delimitation process in North Sea Continental Shelf and Articles 74 and 83 require that the delimitation of the exclusive economic zone and the continental shelf results in an equitable solution. The recurrent discussion of in particular the nature of equity and equitable principles in the case law indicates that the judiciary has grappled to come to terms with these concepts. Chapter 7 looks at the closely related concepts of relevant coasts and relevant area. As Chapter 7 points out, the development of these concepts by the case law has not been linear.

Most decisions on the delimitation of the continental shelf and the exclusive economic zone first determine a provisional delimitation line and then consider whether there are circumstances calling for the adjustment of that line. In most instances, this provisional line has been an equidistance line. Chapter 8 considers the pronouncements of the case law on the principles and criteria applicable to identifying the provisional delimitation line and assesses how does the actual identification of the provisional delimitation line in the case law relates to those principles and criteria. Chapter 9 looks at the concept of relevant circumstances, which are largely identical to the concept of special circumstances contained in Article 6 of the Convention on the Continental Shelf. In this connection, Chapter 9 investigates to what extent relevant circumstances are also playing a role in the other stages than the second stage, at which the case law explicitly takes into account relevant circumstances. Chapter 10 considers 
the role of third states in the delimitation of bilateral boundaries in thirdparty dispute settlement. Third states may impact on the delimitation process mainly in two ways. Their presence may limit the area in which a court or tribunal considers it possible to effect a delimitation. Second, the coast of a third state may be part of the relevant circumstances that need to be taken into consideration in arriving at a final boundary. Chapter 11 focusses on the third-stage proportionality test, which consists of assessing whether the ratio between the relevant coasts of the parties and the ratio of the between the parts of the relevant area attributed to each party does not show a disproportion. Such disproportion would indicate that the delimitation line that is the result of the second stage of the delimitation process does not result in an equitable solution. To put the use of this test in proper perspective, Chapter 11 also considers how the length of the relevant coasts may be used as a relevant circumstance at the second stage of the delimitation process.

Chapters 12 and 13 are concerned with the delimitation of the continental shelf beyond 200 nautical miles. The editors concluded that two characteristics of this part of the continental shelf justified separate treatment of this topic. First, the establishment of the outer limits of the continental shelf beyond 200 nautical miles not only involves the coastal state, but that state is required to submit information on those outer limits to the Commission on the Limits of the Continental Shelf (CLCS) in accordance with Article 76 of the LOSC. The existence of this procedure raises questions concerning its relationship to the delimitation of the continental shelf by dispute settlement bodies. This topic is the subject of Chapter 12. Chapter 13 considers how the case law has addressed the fact that the basis of entitlement to the continental shelf beyond 200 nautical miles, natural prolongation, is different from the distance-based entitlement within 200 nautical miles. Another reason for dealing with the continental shelf beyond 200 nautical miles in two separate chapters is that this concerns a relatively new topic, which may be the subject of further development through the case law as is intimated in these chapters.

Chapter 14 of this volume contains its conclusions and will seek to provide an answer to the central research question of the project: how predictable and consistent has the case law concerning the delimitation of the continental shelf and the exclusive economic zone been? Before drawing together the conclusions of the individual chapters, Chapter 14 will consider the parameters to be used in answering the central research question. As the Statute of the ICJ and the ITLOS indicate a judgment shall 
state the reasons on which it is based. ${ }^{91} \mathrm{~A}$ similar provision in contained in Annex VII of the LOSC setting out the basic rules applicable to arbitration under the Convention. ${ }^{92}$ The Rules of Court of the ICJ and the Rules of the Tribunal of the ITLOS further provide that a judgment shall contain 'a statement of the facts' and 'the reasons in point of law. ${ }^{93}$ Chapter 14 will set out what criteria have been developed to assess whether decisions of international courts and tribunals are rendered in accordance with these requirements.

\subsection{Concluding Remarks}

The development of the regime of the continental shelf and the exclusive economic zone has led to an expansion of coastal state jurisdiction to almost half of the world oceans. The frequent overlap of these zones between neighbouring states - only some mid-ocean islands do not share maritime boundaries with other land territory - resulted in rules on the delimitation of these zones. The general nature of the rules contained in the Convention on the Continental Shelf and the LOSC has contributed to states making ample use of third-party dispute settlement to establish maritime boundaries with their neighbours. This is a trend that is likely to continue. As was pointed out in Section 1.4, the number of boundary disputes that has been submitted to third-party settlement procedures has actually risen as compared to the number of maritime boundaries that have been settled through direct negotiations. Another notable trend is the rise of unilateral applications to third-party dispute settlement mechanisms. This option already existed under a number of instruments, but a new avenue in this respect was created under Section 2 of Part XV of the LOSC. Whether this trend will continue depends, among other factors, on whether states will make use of options to limit the possibilities for making unilateral applications such as a declaration excluding maritime boundary delimitation from compulsory dispute settlement under the LOSC in accordance with its Article 298.

The main focus of this volume concerns the question how predictable and consistent the case law on the delimitation of maritime boundaries has been through time. Section 1.5 in this connection briefly considers how the composition of the bench may impact on this issues and to what extent

91 Statute of the ICJ, Art. 56; LOSC, Annex VI, Art. 30.

92 LOSC, Annex VII, Art. 10.

93 Rules of Court, Art. 95(1); Rules of the Tribunal, Arts. 125(h) and (j). 
criticism from beyond the bench may impact on how judges approach the law. For the reasons set out in Section 1.5, these issues are not pursued in the subsequent chapters of this volume. Section 1.5 briefly compares the judgments on the merits in Tunisia/Libya and Libya/Malta and discusses the individual opinions appended to the latter judgment. If anything, this assessment shows how difficult it is to second-guess what transpires in the internal deliberations of the judiciary. Individual opinions do indicate that voting with majority does not necessarily mean agreement with the reasoning of the judgment even where it concerns critical issues. A number of individual opinions in Libya/Malta moreover indicate that the Court was internally divided as to whether the judgment was successful in making a contribution to the predictability and consistency of the case law on maritime delimitation.

As is set out in Section 1.3, the law on the entitlement to maritime zones and their delimitation has developed through time. This will be one important consideration that has to be factored in while assessing the question whether the case law has been successful in contributing to the predictability and consistence of the law in relation to the delimitation of the continental shelf and the exclusive economic zone. Moreover, as set out in Section 1.6, this volume looks at a number of discrete issues. The development of the case law on these different issues need not necessarily be the same. The significance of the project this project will hopefully consist of making a contribution to the assessment of how the case law has developed the law in an important field and what this may hold in store for the future.

\section{Table 1.1 Maritime Delimitations Submitted to Compulsory Procedures} Entailing Binding Decisions

\begin{tabular}{lc}
\hline \hline A. Joint submission & B. Unilateral submission \\
\hline 1. Grisbadarna (Norway/Sweden) & 1. Aegean Sea Continental Shelf \\
BS: SA (1908) & (Greece v. Turkey) \\
O: DM (1909) & BS: General Act for Pacific \\
MZD: TS & Settlement of International \\
Decided by: A & Disputes (1928) \\
& YA: 1976 \\
& O: AJ (1978) \\
& MZD: CS \\
& Decided by: ICJ
\end{tabular}


Table 1.1 (cont.)

A. Joint submission

2. North Sea Continental Shelf (Germany/Netherlands)

BS: SA (1967)

O: DM (1969)

MZD: CS

Decided by: ICJ

3. North Sea Continental Shelf case (Germany/Denmark)

BS: SA (1967)

O: DM (1969)

MZD: CS

Decided by: ICJ

4. Case concerning the delimitation of continental shelf between the United Kingdom of Great Britain and Northern Ireland, and the French Republic

BS: SA (1975)

O: DM (1977)

MZD: CS

Decided by: A

5. Case concerning a dispute between Argentina and Chile concerning the Beagle Channel BS: SA (1971) O: DM (1977)

MZD: TS

Decided by: A
B. Unilateral submission

2. Maritime Delimitation in the Area between Greenland and Jan Mayen (Denmark v. Norway)

BS: OC

YA: 1988

O: DM (1993)

MZD: CS/FZ

Decided by: ICJ

3. Land and Maritime Boundary between Cameroon and Nigeria (Cameroon v. Nigeria: Equatorial Guinea intervening)

BS: OC

YA: 1994

O: DM (2002)

MZD: TS/CS/EEZ

Decided by: ICJ

4. Territorial and Maritime Dispute between Nicaragua and Honduras in the Caribbean Sea (Nicaragua v. Honduras) BS: Pact of Bogotá and OC YA: 1999

O: DM (2007) MZD: TS/CS/EEZ Decided by: ICJ

5. Territorial and Maritime Dispute (Nicaragua v. Colombia)

BS: Pact of Bogotá

YA: 2001

O: DM (2012)

MZD: CS/EEZ

Decided by: ICJ 
Table 1.1 (cont.)

A. Joint submission

6. Case concerning the continental shelf (Tunisia/Libya)

BS: SA (1977)

O: DM (1982)

MZD: CS

Decided by: ICJ

7. Case concerning delimitation of the maritime boundary in the Gulf of Maine area (Canada/USA)

BS: SA (1979)

O: DM (1984)

MZD: CS/FZ

Decided by: ICJ

8. Case concerning the continental shelf (Libya/Malta)

BS: SA (1976)

O: DM (1985)

MZD: CS

Decided by: ICJ

9. Case concerning the delimitation of the maritime boundary between Guinea and Guinea-Bissau

BS: SA (1983)

O: DM (1985)

MZD: TS/CS/EEZ

Decided by: A
B. Unilateral submission

6. Maritime Delimitation in the Black Sea (Romania v. Ukraine) BS: Additional Agreement to the

Treaty on the Relations of

Good Neighbourliness and

Co-operation (1997)

YA: 2004

O: DM (2009)

MZD: CS/EEZ

Decided by: ICJ

7. In the Matter of an Arbitration between Barbados and the Republic of Trinidad and Tobago (Barbados v. Trinidad and Tobago)

BS: LOSC

YA: 2004

O: DM (2006)

MZD: CS/EEZ

Decided by: A

8. In the Matter of an Arbitration between Guyana and Suriname (Guyana v. Suriname)

BS: LOSC

YA: 2004

O: DM (2007)

MZD: TS/CS/EEZ

Decided by: A

9. Maritime Dispute (Peru v. Chile)

BS: Pact of Bogotá

YA: 2007

O: DM (2014)

MZD: TS/CS/EEZ

Decided by: ICJ 
Table 1.1 (cont.)

A. Joint submission

10. Case concerning the delimitation of maritime boundary between

Guinea-Bissau and Senegal

BS: SA (1985)

O: DM (1989)

MZD: TS/CS

Decided by: A

11. Case concerning the delimitation of maritime areas between Canada and France

BS: SA (1989)

O: DM (1992)

MZD: CS/EEZ

Decided by: A

12. Case concerning maritime delimitation and territorial questions between Qatar and Bahrain

BS: SA $(1987 / 1990)^{b}$

O: DM (2001)

MZD: TS/CS

Decided by: ICJ

13. In the matter of an Arbitration pursuant to an Agreement to Arbitrate dated 3 October 1996 between the Government of the State of Eritrea and the Government of the Republic of Yemen

BS: SA (1996)

O: DM (1999)

MZD: TS/Cs/EEZ

Decided by: A
B. Unilateral submission

10. Dispute concerning delimitation of the maritime boundary between Bangladesh and Myanmar in the Bay of Bengal ${ }^{a}$

BS: LOSC

YA: 2009

O: DM (2012)

MZD: TS/CS/EEZ

Decided by: ITLOS

11. In the matter of the Bay of Bengal maritime boundary arbitration (Bangladesh v. India)

BS: LOSC

YA: 2009

O: DM (2014)

MZD: TS/CS/EEZ

Decided by: A

12. Question of the Delimitation of the Continental Shelf between Nicaragua and Colombia beyond 200 nautical miles from the Nicaraguan Coast (Nicaragua v. Colombia)

BS: Pact of Bogotá

YA: 2013

O: Pending

MZD: CS

Decided by: ICJ

13. Maritime Delimitation in the Caribbean Sea and the Pacific Ocean (Costa Rica v. Nicaragua)

BS: Pact of Bogotá

YA: 2014

O: Pending

MZD: TS/CS/EEZ

Decided by: ICJ 
Table 1.1 (cont.)

\begin{tabular}{ll}
\hline \hline A. Joint submission & B. Unilateral submission \\
\hline 14. Territorial and Maritime & 14. Maritime Delimitation in the \\
Arbitration between Croatia and & Indian Ocean (Somalia v. Kenya) \\
Slovenia & BS: OC \\
BS: SA (2009) & YA: 2014 \\
O: Pending & O: Pending \\
MZD: TS & MZD: TS/CS/EEZ \\
Decided by: A & Decided by: ICJ \\
& 15. Dispute concerning Delimitation \\
& of the Maritime Boundary \\
& between Ghana and Côte d'Ivoire \\
& in the Atlantic Ocean \\
& (Ghana/Côte d'Ivoire) ${ }^{c}$ \\
& BS: LOSC \\
& YA: 2014 \\
& O: Pending \\
& MZD: TS/CS/EEZ \\
& Decided by: ICJ
\end{tabular}

Note: The table only lists cases between states and not between entities that form part of federal states. The table does not lists incidental procedures unless these resulted in a discontinuation of the proceedings. A: arbitration; AJ: finding that there was no basis of jurisdiction; BS: basis of submission; CS: continental shelf; DM: decision on the merits; EEZ: exclusive economic zone; FZ: fishery zone; MZD: maritime zone subject of the proceedings; O: outcome; OC: declarations under Article 36(2) of the Statute of the ICJ; SA: agreement between the parties to submit the specific dispute; TS: territorial sea; YA: year of application.

${ }^{a}$ The case was initiated unilaterally by Bangladesh. The parties subsequently agreed to joint submission to the ITLOS. ${ }^{b}$ The case was referred to the ICJ by an Application of Qatar. However, the case is listed as a joint submission because, as was held by the International Court of Justice in a judgment of 1 July 1994, by the terms of two international agreements of respectively 1987 and 1990 'the Parties had undertaken to submit to the Court the whole of the dispute between them' (Judgment of 1 July 1994 ([1994] ICJ Rep. 112 [41(2)]). ${ }^{c}$ The case was initiated unilaterally by Ghana. The parties subsequently agreed to joint submission to a Special Chamber of the ITLOS. 